Research Paper

\title{
Prediction of Psychological Disturbances in Mothers of Children with Autism Spectrum Disorder based on Mindfulness and Rumination
}

\author{
Bahman Akbari*1 \\ 1. Associate Professor, Department of Psychology, Rasht Branch, Islamic Azad University, Rasht, Iran \\ Received: May 24, 2018 \\ Accepted: March 1, 2019
}

\begin{abstract}
Background and Purpose: Autism spectrum disorder is one of the most difficult childhood disorders that is characterized by persistent degeneration in social interaction, communication, repetitive behaviors, and limited interests. The multiple problems of these children cause family members, especially the mother, to be disturbed and tense. The purpose of this study was to predict the psychological disturbances of mothers of children with autism spectrum disorder based on mindfulness and rumination.

Method: The design of this research is descriptive and correlational. The statistical population of the study consisted of all mothers of children with ASD referring to the centers of children with special needs in Rasht city in the first semester of the academic year 2017-2018. Among these mothers, 96 were selected by random sampling method. The subjects responded to the questionnaires of mind-consciousness (Baer et al., 2006), rumination (Nullen and Hoeksma, 1991), and psychological distress (Kessler et al, 2002). The data were analyzed using Pearson correlation coefficient and stepwise regression.

Results: The findings of the study showed that there was a negative significant relationship between the total score of mindfulness and the subscales of observation, action with Knowledge, and non-judgment of the inner experience, and the psychological disturbance of the mothers with autistic children $(\mathrm{p}<0 / 0001)$. Also, the results of regression analysis indicated that mindfulness and its subscales, as well as rumination (with a confidence of 99\%), could predict changes in the variables of psychological disturbances of mothers of children with ASD.

Conclusion: According to the findings of this study, it can be concluded that mindfulness and rumination can predict the psychological disturbances in mothers of children with ASD. The implication of the result obtained in this paper is discussed.
\end{abstract}

Keywords: Autism spectrum, rumination, psychological disturbances, mindfulness

Citation: Akbari B. Prediction of psychological disturbances in mothers of children with autism spectrum disorder based on mindfulness and rumination. Quarterly Journal of Child Mental Health. 2019; 6(1): 200-210.

* Corresponding author: Bahman Âkbari, Associate Professor, Department of Psychology, Rasht Branch, Islamic Azad University, Rasht, Iran. 


\title{
بيشبينى آشفتكى روانشناختى مادران داراى كودكى مبتلا به اختلال طيف اوتيسم بر اساس ذهن آكاهى و نشخوار فكرى
}

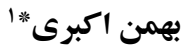 \\ 1. دانشيار گروه روانشناسى، واحد رشت، دانشكاه آزاد اسلامى، رشت، ايران
}

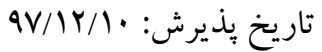

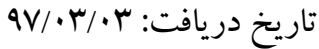

\section{جكکب:}

زمينه و هدف: اختلال طيف اوتيســم يكى از دشــوارترين اختلالات دوران كودكى اســت كه با تخريب بايدار در تعامل اجتماعى،

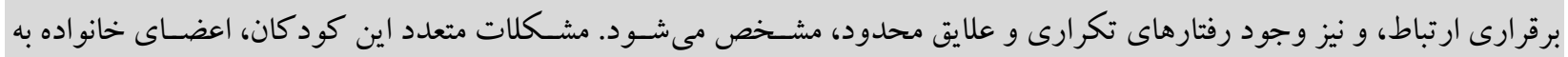

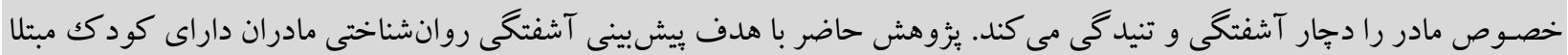

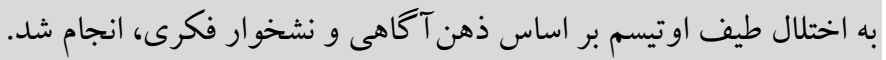
روش: طرح اين يثزوهش، توصيفى و از نوع همبستخى است. جامعه آمارى بزوهش شامل تمامى مادران داراى كودك مبت مبتلا به اختلال

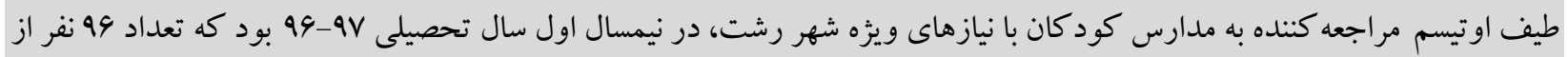

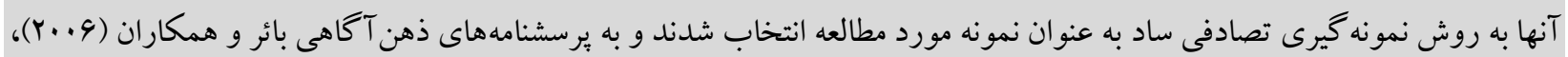

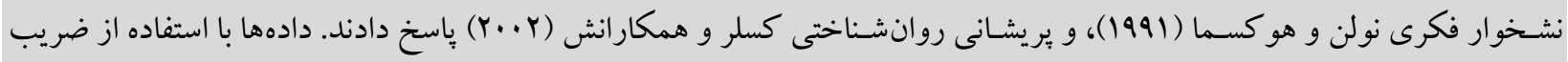

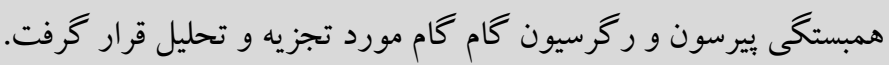

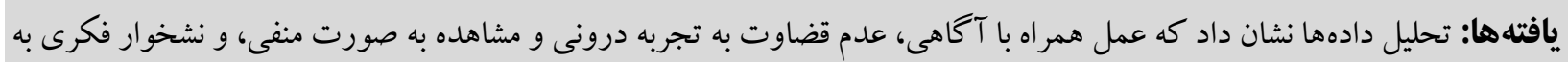

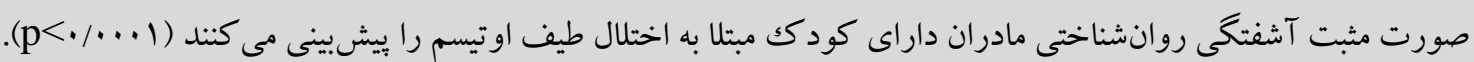

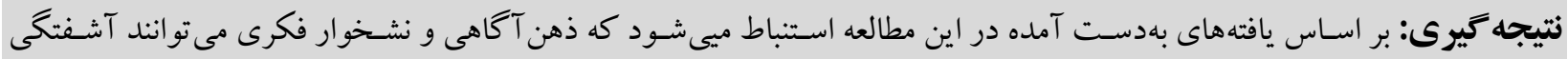

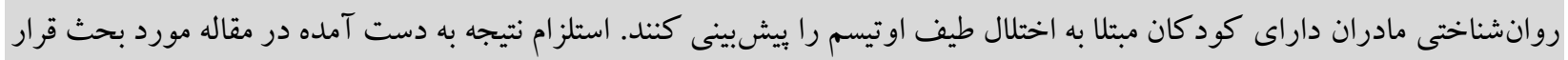
كرفته است. كليد وازهها: طيف اوتيسم، ذهن آكاهى، نشخوار فكرى، آشفتگى روانشناختى

*نويسنده مسئول: بهمن اكبرى، دانشيار گروه روانشناسى، واحد رشت، دانشكاه آزاد اسلامى، رشت، ايران. 
حـال نسـبـت بـه تجربهاى كه در يكك لحظه خاص در

مقدمه محدوده توجه يكك فرد قرار دارد؛ علاوه بر آن، اين مفهوم اختلال طيف اوتيسم، اختلال عصبى -تحولى است كه تظاهرات

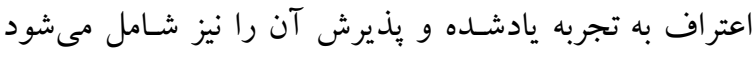

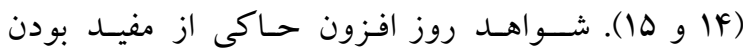

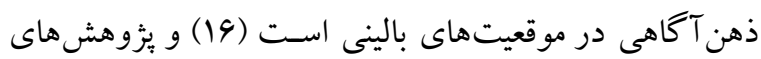

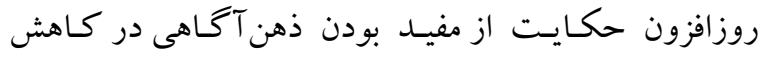

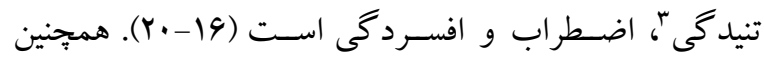

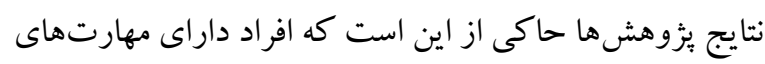

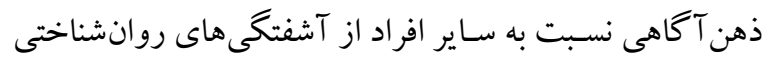

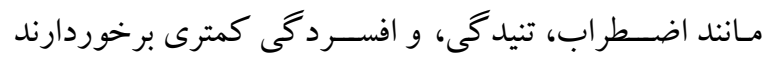
(YY). در بززوهش هاى فروزش يكتا و همكاران (YM)، كلدين

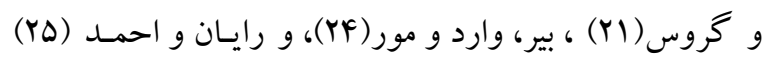

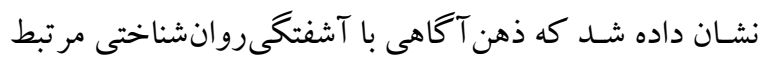
اسـت و افزايش ذهن آكاهى موجب كاهش آشـفتخى روانشـناختى مى شــود. نتايج يزوهش ها نشـان مى دهد كه والدين

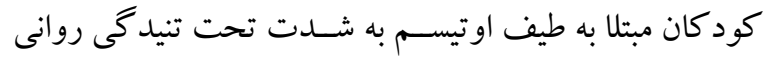
بوده و مستعد مشكلات و آشفتخى روانشناختى هستند (Y\&). وليكن والدينى كه ذهن آكاهى بيشترى دارند در رويارويى با

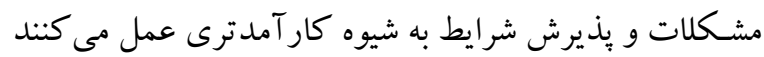

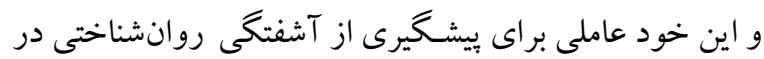

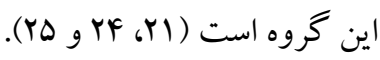

ويزّ گى ديخرى كه در مادران كود كان داراى اختلال طيف

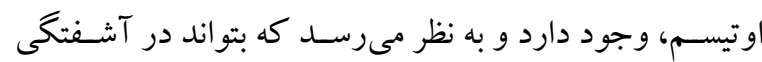

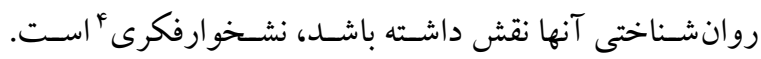

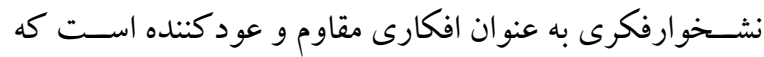
حول يـك موضــوع معمول دور مىزنـد. اين افكار به طريق

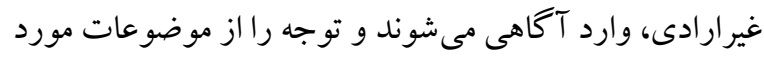
نظر و اهداف فعلى منحرف مىسازند (YV). ئزوهشهاى انجام

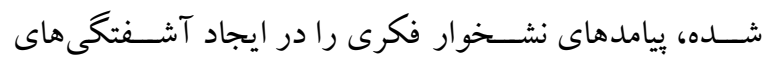

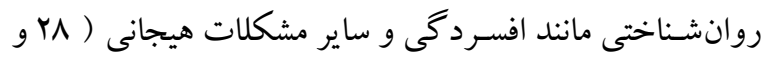


توجـه به شـــرايط ورود و خروج از يزوهش تعداد • ل11 نفر به عنوان نمونه انتخاب و به برسـشـنامه هاى يُزوهش بِاسـخ دادند.

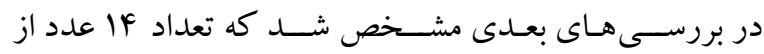

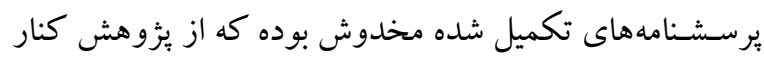

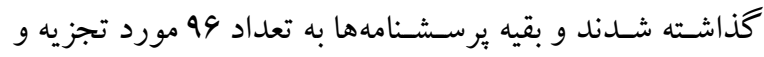

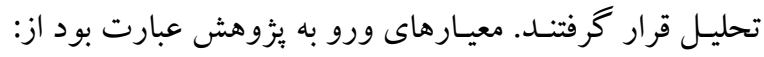

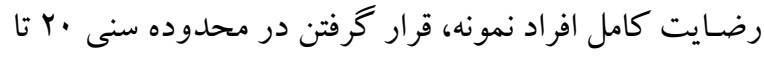

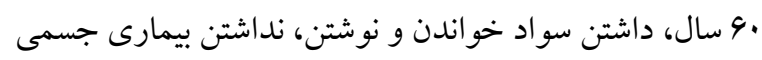
و روانشـناختى معنادار؛ و معيارهاى خروج از يثزوهش شـامل اعلام عدم رضايت از ادامه شركت در يثوهش و عدم همكارى لازم در تكميل فرمها و برسشنامهها، بود. ب) ابزار: جهت جمع آورى اطلاعات از ابزارهاى زير اسـتفاده

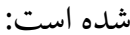
ا. يرسشنامه ينجوجهى ذهن آكاهى' ': اين مقياس توسط بائر و

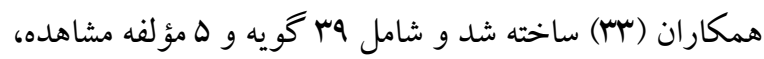
توصيف، عمل همر اه با آكاهى، عدم قضاوت به تجربه درونى، و عدم واكنش به تجربه درونى در قالب طيف ليكرت از هركز ا تا هميشـه ها اسـت (MF). بر اسـاس نتايج تحليل عاملى انجام شـده، همسـانى درونى عامل هاى اين برسـشــامه مناسب بود و

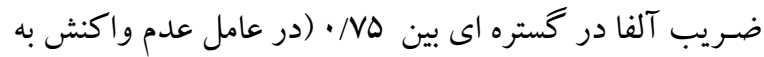
تجربـه درونى) تـا ا9/• (در عامل توصـيف) به دسـت آمد. همبسـتخى بين عامل ها متوسـط و در همه موارد معنىدار بود و

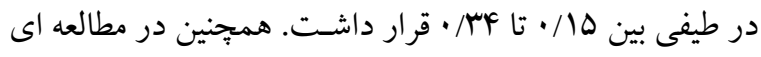

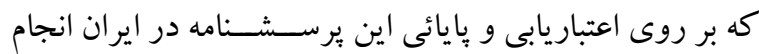

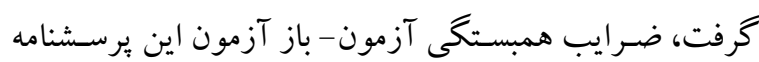

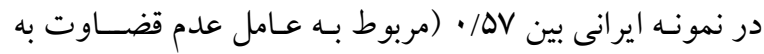
تجربه درونى) و AF/ • (عامل مشــاهده) قرار داشـت. هم:جنين ضرايب آلفا در حد قابل قبولى بين هه/· • (مربوط به عامل عدم

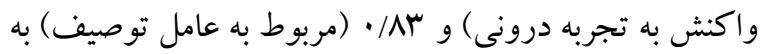

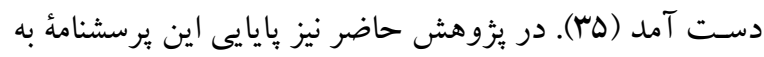

$$
\text { روش آلفاى كرونباخ 191• به دست آمد. }
$$

و9) واختلـالات اضـطر ابى يا خشــم را تأييد مى كنند (Yq).

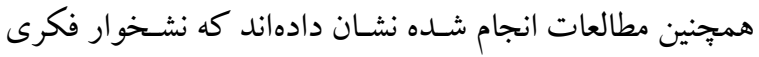

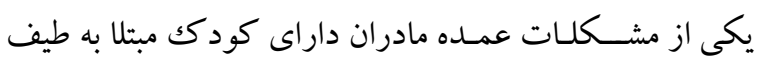

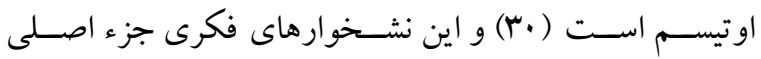

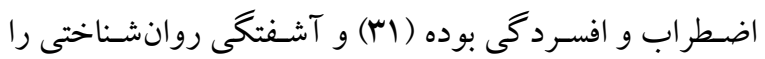

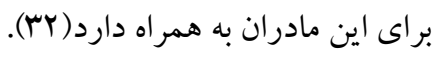
در مجموع، مادران داراى كود كك اختلال طيف اوتيسـم به مانه

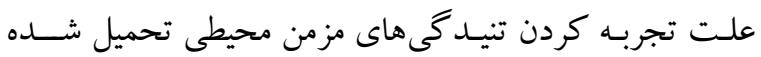

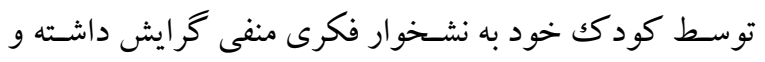
رويدادهاى محيطى را به اشـكال منفى تعبير و تفسـير مى كنند كه به نوبه خود زمينه كاهش سطح بهزيستى ذهنى و موجبات

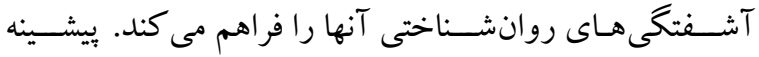
يثزوهشى در زمينه عوامل دخيل در آشفتكى روانشناختى اين مادران محدود بوده و با توجه به اهميت سـلامت روانشـناختى

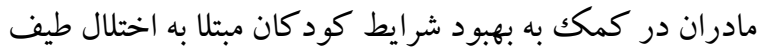
اوتيســم، ضــرورت دارد كه يزوهش هاى بيشـترى در زمينه

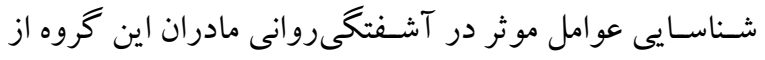
كود كان انجام شود تا بتوان برنامههاى جامع ترى در در كمكك به بهبود شر ايط خانو ادههاى داراى كود كك مبتلا به اوتيسم طر احى نـ

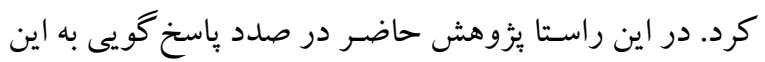
سوال است كه آيا آشفتخى روانشناختى بر اساس ذهن آكَاهى

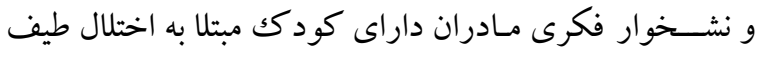
اوتيسم، قابل بيشبينى است؟

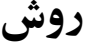
الف) طرح هزوهش و شـر كت كنند كان: روش اين يزوهش

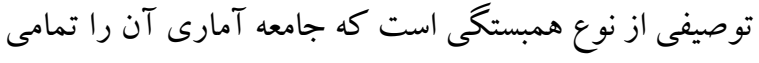
مادران داراى كود كك مبتلا به اختلال طيف او تيسم مر اجعه كننده به مدارس كود كان با نيازهاى ويزه شهر رشت، در نيمسال اول

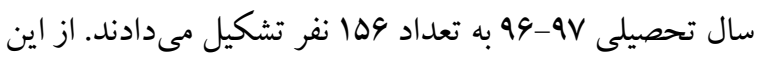

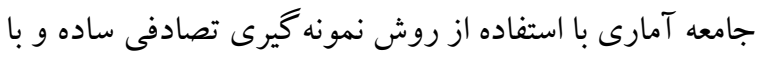


كردآورى نموده و طبقهبندى كردند و بس از طبقهبندى آنها

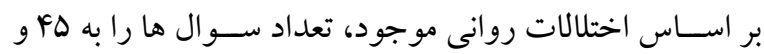

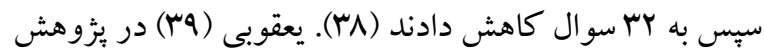

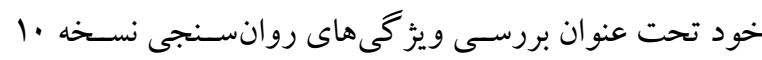
ســالى مقياس يريشـانى روانشــاختى كسـلر، ميزان اعتبار و

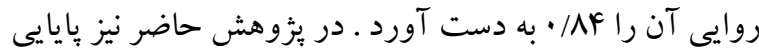

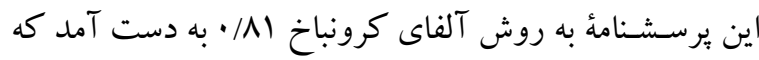
مطلوب است. ج) روش اجرا: بِ از كسب مجوزهاى للازم براى اجراى اين يزوهش، به مدارس با نيازهاى ويزه شهر رشت مر اجعه شد و با اسـتفاده از روش نمونه گيرى تصـادفى، نمونه آمارى انتخاب شـدند و برسـشنامه هاى يُزوهش را تكميل كردند. لازم به ذكر اسـت بيشـتر ملاحظات اخلاقى مربوط به انجمن روانشـناسـى

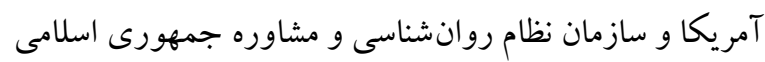
ايران در اين مطالعه به طور كامل رعايت شد. بدين منظور ابتدا

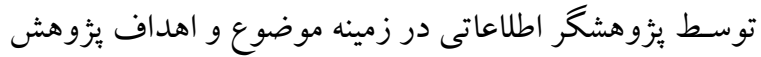
به شر كت كنند كان داده شد و همجينين به آنها اطمينان داده شد كه اطلاعات به صـورت گروهى تحليل مى شــود و اطلاعات فردى آنها محر مانه باقى خو اهد ماند. در مر حله بعد رضــايت شـركت كنند كان به طور كامل جلب شـــــ و اين امكان به آنها

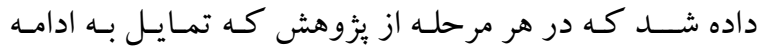
همكارى نداشتند، از شر كت در يزوهش انصر اف دهند.

\section{يافتهها}

در جدول اشـاخص هاى توصسيفى متغيرهاى يزوهش اعم از

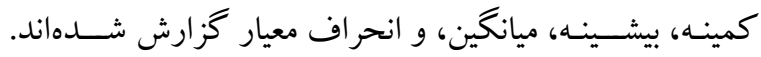
هم:جنين براى بررسـى نرمـال بودن توزيع متغيرهـا از آزمون

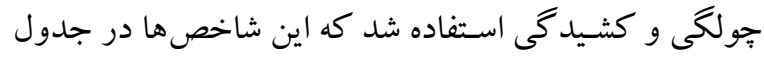

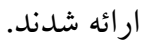

r. مقياس ياسخحاى نشخوارى': نولن- هو كسما در سال 1991

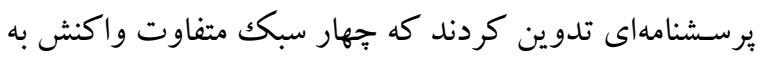

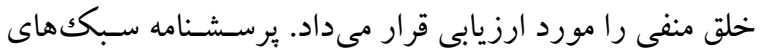

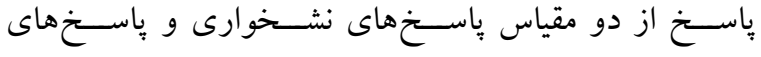
منحرف كننده حواس تشكيل شده است. اين مقياس r عبارت

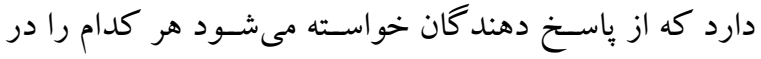
مقياسى از |(هركز ) تا F (اغلب اوقات) درجهبندى كنند. دامنه نمرات اين يرسـشنامه بين · الى 94 قرار دارد كه نمره سب نقطه برش برسـشنامه است و نمرات كمتر از سل نشاندهنده نشخوار فكرى بائين و نمرات بيشتر از آن نشاندهنده نشخوار فكرى بالا اسـت (Y4). بر بايه شواهد تجربى، مقياس بِاسخهاى نشخوارى

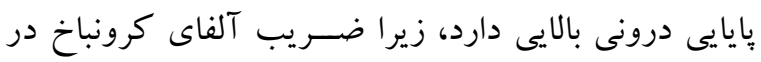

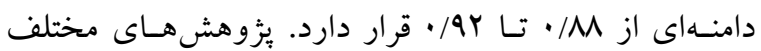

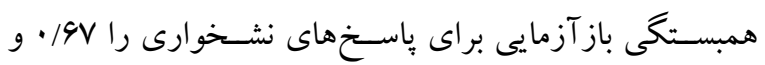

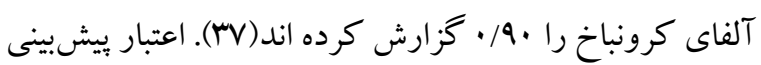
مقياس باسـخهاى نشخوارى در تعداد زيادى از مطالعات مورد آزمايش قرار كرفته كه قابل اعتماد بودن اين ابزار را تاييد

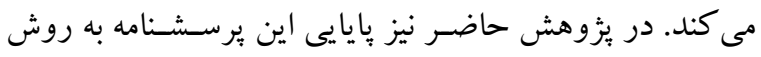
آلفاى كرونباخ لهو • به دست آمد.

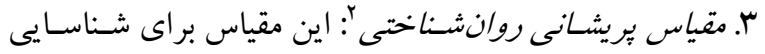
اختلالات روانى در جمعيت عمومى توسط كسلر و همكار انش برسي

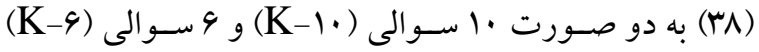
تدوين شــده و در مطالعات مختلف مورد اســفاده قرار خرفته

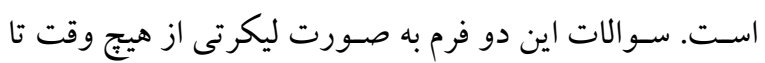
هميشه و از صفر تا •F نمره گذارى مى شود كه حداكثر نمره به دست آمده در اين ابزار ·F اسـت. فرم · اسوالى اين مقياس، اختلال روانشــناختى خاصسى را هدف قرار نمى دهد، اما در مجموع سطح اضطر اب و علائم افسردكى را كه فرد طى خهند هفته اخير تجربه كرده، مشــخص مى كند. كسـلر و همكاران

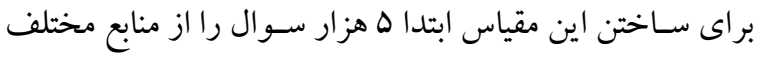


جدول 1: شاخصهاى توصيفى متغيرهاى بزوهش

\begin{tabular}{|c|c|c|c|c|c|c|}
\hline كشيدتى & جولكى & انحر اف معيار & ميانكين & بيشينه & كمينه & متغير \\
\hline$-\cdot 1 \cdot 1$ & $\cdot / 1 r$ & $\Delta / r \Lambda$ & $11 r / \Delta r$ & Irr & 1.1 & نمره كل ذهن آكاهى \\
\hline$-\cdot / r \Delta$ & $\cdot / 4 q$ & $r / \Delta q$ & $r F / r r$ & r. & 19 & مشاهده \\
\hline-.194 & $-\cdot / 49$ & $r / . r$ & $r \cdot / 1)$ & rF & iv & توصيف \\
\hline$-\cdot / \mu$ & $\cdot / \pi r$ & $1 / 10$ & YF/AY & rq & rr & عمل همراه با آكاهى \\
\hline.$- / \cdot \Delta$ & -.1 .9 & $r / F$. & $r F / \Delta q$ & rq & r) & عدم قضاوت به تجربه درونى \\
\hline$-\cdot 191$ & $\cdot / \Delta 1$ & $r / T r$ & $19 / 4 \Lambda$ & rF & 19 & عدم واكنش به تجربه درونى \\
\hline$-\cdot / \Delta 9$ & . & $\Delta / 1 T$ & rN/AY & 4. & fr & نشخوار فكرى \\
\hline$\cdot / r r$ & $\cdot / r$ & $\Delta / .9$ & if & r4 & $\wedge$ & آشفتخى روانشناختى \\
\hline
\end{tabular}

فكرى با آشفتگى روانشناختى مادران داراى كود كان مبتلا به با توجه به نتايج جدول ا، قدر مطلق جولكى و كشيدگى اختلال طيف اوتيسم از ضريب همبستخى ييرسون استفاده شد. براى تمامى متغيرها كمتر از ا است، بنابراين مىتوان نتيجه در جدول Y ماتريس همبستخى رابطه بين ذهن آكاهى و نشخوار

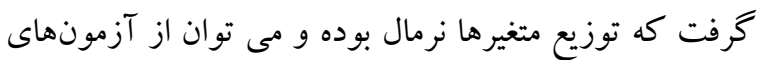
فكرى با آشفتخى روانشناختى گز ارش شده است.

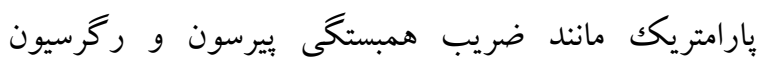
جند گانه استفاده كرد. براى بررسى رابطه ذهن آكاهى و نشخوار جدول r: ماتريس رابطه بين ذهن آكاهى و نشخوار فكرى با آشفتعى روانشناختى

\begin{tabular}{|c|c|c|c|c|c|c|c|c|c|}
\hline$\hat{\Lambda}$ & 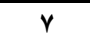 & 7 & 0 & $\varepsilon$ & $r$ & $r$ & 1 & متغير & شماره \\
\hline & & & & & & & 1 & ذهن Tكاهى & 1 \\
\hline & & & & & & 1 & $\cdot N^{* * *}$ & مشاهده & r \\
\hline & & & & & 1 & $\cdot / r I^{*}$ & $\cdot / 4 \Lambda^{* *}$ & توصيف & $r$ \\
\hline & & & & 1 & $\cdot /\left.\right|^{* * *}$ & $\cdot / \mu \mu^{* * *}$ &.$/ 9 Y^{* *}$ & عمل همراه با آكاهى & f \\
\hline & & & 1 & $\cdot /\left.\Delta\right|^{* * *}$ & $\cdot / \pi \mu^{*}$ & $\cdot / r F^{*}$ & $\cdot / 0 \cdot * *$ & عدم قضاوت به تجربه درونى & $\Delta$ \\
\hline & & 1 & $-\cdot / 19$ & $-\cdot / r \Delta^{* * *}$ & $-\cdot / 4 \Lambda^{* * *}$ & $-\cdot /\left.r\right|^{*}$ & $-\cdot / \varphi^{* *}$ & عدم واكنش به تجربه درونى & 4 \\
\hline & 1 & $\cdot / r^{*}$ & $-\cdot / Y F^{*}$ & $-\cdot / 4 q^{* * *}$ & $-\cdot / \Gamma V^{* *}$ & $-\cdot / r 4^{* *}$ & $-\cdot / \kappa \psi^{* *}$ & نشخوار فكرى & $\checkmark$ \\
\hline 1 & $-\cdot / r \Delta^{* * *}$ & $-\cdot / 1 \wedge$ & $-\cdot / \mathscr{F} \Lambda^{* * *}$ & $-\cdot / 90^{* *}$ & $-\cdot / 11$ & $-\cdot / \Gamma V^{* *}$ & $-\cdot / \Delta q^{* * *}$ & آشفتخى روانشناختى & $\wedge$ \\
\hline
\end{tabular}

كود كان مبتلا به اختلال طيف اوتيسم كاهش مى يابد و برعكس با كاهش اين متغيرها، ميزان آشــفتخى روانشـــناختى مادران

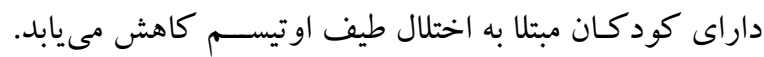
براى بيشبينى آشـفتخى روانشـناختى مادران داراى كود كان

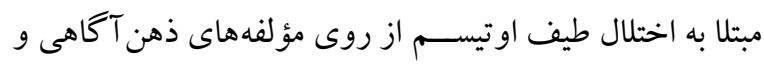

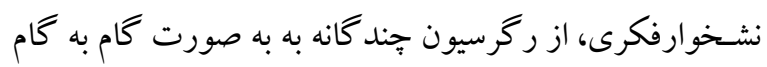

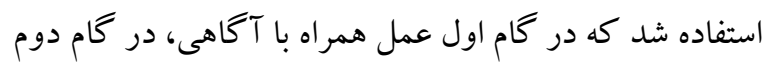
عدم قضــاوت به تجربه درونى، كام ســوم مشـــاهده، و و كام جهارم نشخوار فكرى وارد معادله شده و معنى دارى خود را در

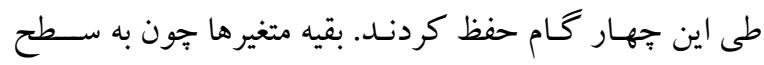

بـا توجه به نتايج جدول r رابطه ذهن آكاهى (r) (r=-)،

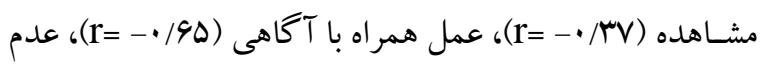

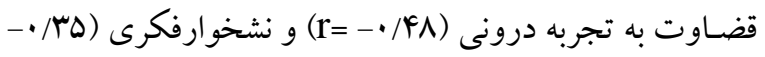
(r= اختلال طيف او تيسـم مثبت و در سطح 1 • • معنى دار است؛ در حسالى كـه بين توصـيف و عـدم واكنش بـه تجربـه درونى بـاـ آشـفتكى روانشـناختى مادران داراى كود كان مبتلا به اختلال

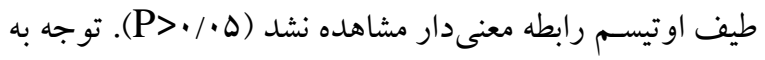
اين يافتها مى توان كفت كه با افزايش ذهن آكَاهى، مشـاهده،

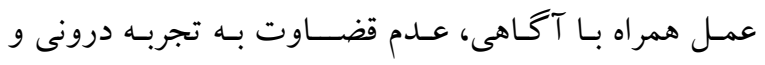

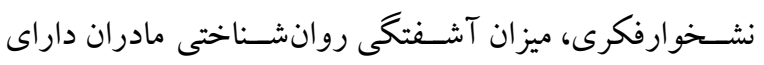


معنى دارى نرسـيدند از معادله حذف شـدند. در جدول ب نتايج تحليل رگرسيون گزارش شده است.

جدول ": خلاصه مدل ركر سيون، تحليل واريانس و مشخصههاى آمارى ركرسيون آشفتگى روانشناختى بر متغيرهاى بيش بين

\begin{tabular}{|c|c|c|c|c|c|c|c|c|c|}
\hline$\Delta \mathbf{R 2}$ & $\mathbf{R 2}$ & $\mathbf{R}$ & $\mathbf{P}$ & $\mathbf{F}$ & ميانكين مجذورات & درجه آزادى & مجموع مجذورات & مدل & كام \\
\hline \multirow[t]{2}{*}{.$/ 41$} & $\cdot / F Y$ & .190 & $\% 1$ & $9 N / Y$. & $1 . Y Y / \Delta \Lambda$ & 1 & $1 . Y Y / \Delta \Lambda$ & رغرسيون & 1 \\
\hline & & & & & $1 F / 99$ & Qf & $|f \cdot q / 4|$ & باقيمانده & 1 \\
\hline \multirow[t]{2}{*}{$\cdot / q F$} & $\cdot / F \Delta$ & $\cdot / 9 \mathrm{~V}$ & $\%$ & $r / \mu$. & $\Delta F Q / Y r$ & r & $1.91 / F F$ & ركرسيون & $y_{1}$ \\
\hline & & & & & $\mid q / \mu F$ & q & I & باقيمانده & 1 \\
\hline \multirow[t]{2}{*}{.$/ 0$} & $\cdot / \Delta 1$ & $\cdot / N r$ & $\%$ & $r Y / Y r$ & $k \mid \Delta / r \Delta$ & r & $|r| 9 \mid \cdot 0$ & رگرسيون & $r$ \\
\hline & & & & & $1 Y / \Lambda q$ & ar & $11 \wedge \Delta / Q \Delta$ & باقيمانده & \\
\hline \multirow[t]{2}{*}{$\cdot / \Delta F$} & $\cdot / 09$ & $\cdot / N \Delta$ &.$\cdots 1$ & $r Q / Y r$ & TFI/AD & r & $1 \mathrm{rgV} / \mathrm{rq}$ & ركرسيون & $x$ \\
\hline & & & & & $11 / \mathrm{v}$. & 91 & $1.94 / 91$ & باقيمانده & \\
\hline
\end{tabular}

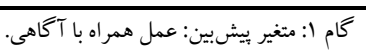

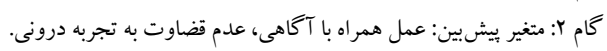

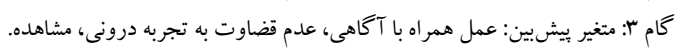

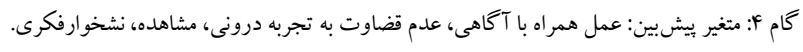

درصسـد، و نشــخوار فكرى ا درصسـد از تغييرات آشــفتكى روانشـناختى را بيشبينى مى كنند. ميزان F مشاهده شده بران

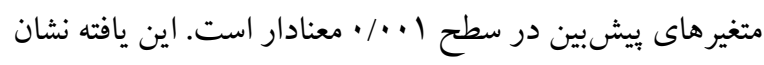

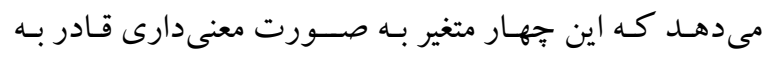

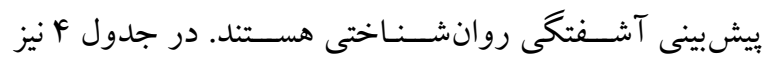

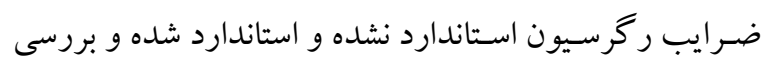
معنادارى اين ضرايب ززارش شدهاند.

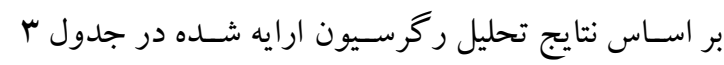
مى توان نتيجه گرفت كه مجموع متغيرهاى ييشبين (مؤلفه نهاى

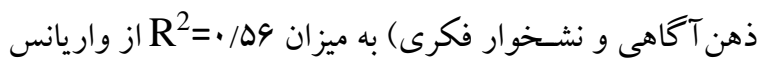

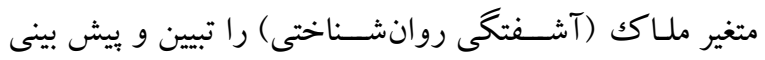

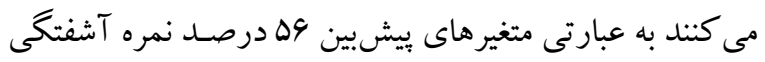

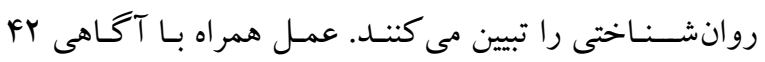
درصـد، عدم قضـاوت به تجربه درونى ب درصـد، مشـاهده 4

جدول ع: ضرايب ركرسيون كام به كام آشفتغى روانشناختى روى متغير هاى ييش بين

\begin{tabular}{|c|c|c|c|c|c|}
\hline $\mathbf{P}$ & $\mathbf{t}$ & $\beta$ & خطاى استاندارد b & B & شاخصها \\
\hline $\mathbf{r}$ & $\mathrm{t}$ & $\boldsymbol{J}$ & 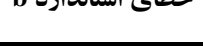 & $\mathbf{D}$ & متغير ها \\
\hline$\cdot / \cdot 1$ & $\Lambda / \mp \wedge$ & & $\mid F / T \Lambda$ & $I r \cdot / I V$ & عدد ثابت (a) \\
\hline$\% \cdot \cdot 1$ & $-4 / 19$ & $-\cdot / r q$ & $\cdot / 41$ & $-1 / N$ & عمل همراه با آكاهى \\
\hline 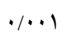 & $-k / N q$ & $-\cdot / 4 \mathrm{~V}$ & $\cdot / r \mid$ &.$- / 99$ & عدم قضاوت به تجربه درونى \\
\hline$\% \cdot 1$ & $-F / N 1$ &.$- / 94$ &.$/ 19$ & $-\cdot / M$ & مشاهده \\
\hline$\% r$ & $r / r r$ & $\cdot / 41$ & . & $\cdot / 41$ & نشخوار فكرى \\
\hline
\end{tabular}

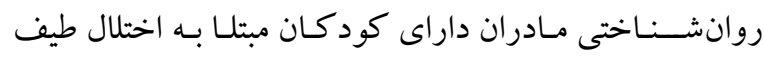

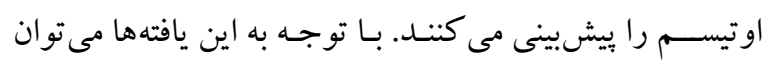

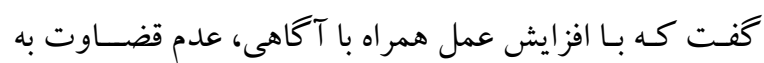
تجربـه درونى و مشــاهـــه و كـاهش نشــخوار فكرى، ميزان
با توجه به جدول F اثر عمل همر اه با آكاهى، عدم قضاوت

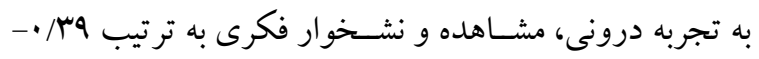

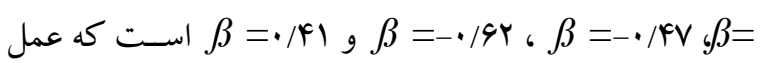
همر اه با آكاهى، عدم قضــاوت به تجربه درونى و مشــاهده به

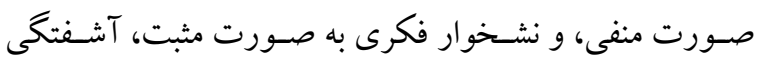


مفيــ را انتخـاب كنــ؛ بـه جـاى آن كـهـ بـه طور خودكـار بـا روشهاى خو گر فته شـده و ناهشـيار واكنش نشـان دهد (rN).

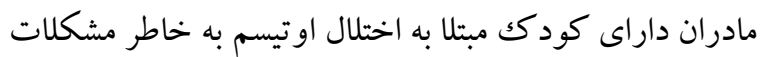
رفتـارى و ارتباطات اجتماعى مختل فرزندشــان در محيطهاى اجتماعى مختلف نمى توانند مشـتاقانه حضسور يابند و به تدريج

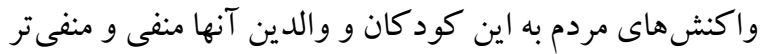
مىشـود (4) و در نتيجه زمينههاى آشـفتخى روانشناختى مادر

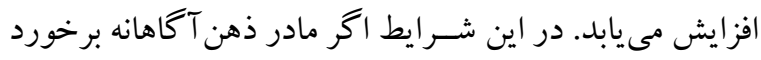

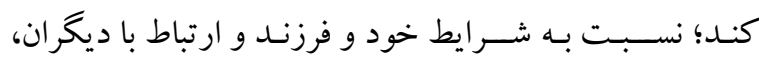
غيرقضاوتى برخورد كند؛ و با بينش به اين شرايط و روابط، به

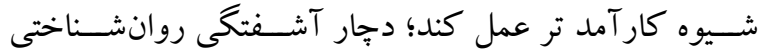
كمترى مىشـود. از اصـول ديخر ذهن آكاهى، داشـتن توانايى رهـا كردن اســت. در درمـانهاى مبتنى بر ذهن آكاهى (Yr)

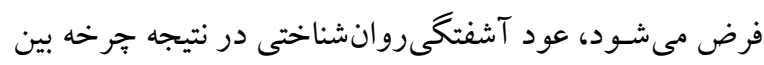

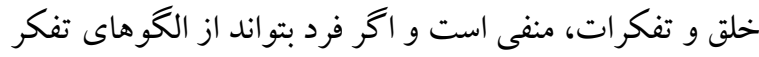

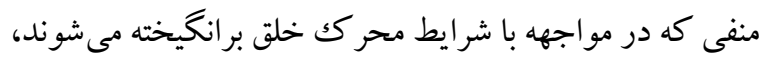

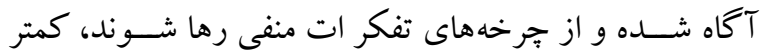

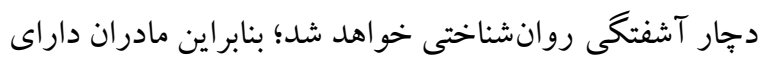
ذهن آكاهى بالاتر، راحت تر مى تواند خود راته را از اين افكار رها كرده و كمتر دجار آشفتكى روانشناختى شوند و بالعكس. نتايج آزمون فرضسيه ديكر اين يثروهش مبنى بر اينكه بين نشخوار فكرى و آشفتخى روانشناختى مادران داراى كود كك

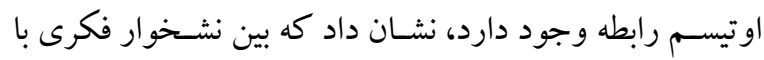

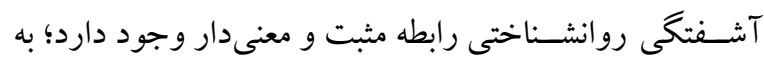

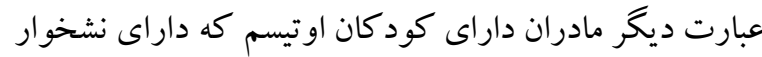

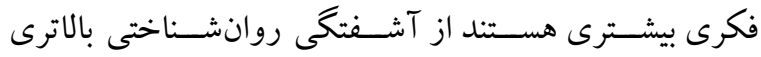
برخوردارند و بالعكس. بيشينه هاى بزٔوهشى حاكى از محدود

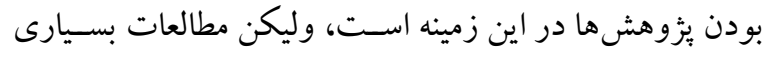
رابطه بين نشـخوار فكرى و اختلالات هيجانى را تأييد مى كنند

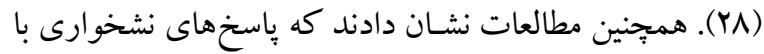
قدرت انطباق ضـعيف تر، خصـومت و تنيدگى، رابطه بيشـتر دارد. نتايج حاصـل را مى توان بر اسـاس ويز گیىهاى نشـخوار
آشـفتخى روانشــاختى مادران داراى كود كان مبتلا به اختلال

$$
\text { طيف اوتيسم كاهش مى يابد. }
$$

\section{بحث و نتيجل كيرى}

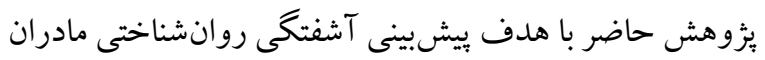
داراى كودكـان مبتلـا بـه اختلـال طيف اوتيســـم بر اســــاس ذهن آكاهى و نشـخوار فكرى، اجرا شـد. نتايج آزمون فرضسيه نشـان داد كه بين ذهن آكَاهى و آشـفتكى روانشناختى ونى مادران داراى كودكك مبتلا به اوتيسـم رابطه منفى و معنادارى وجود

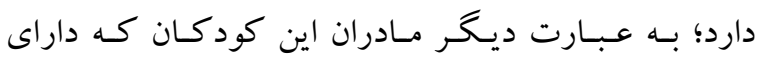

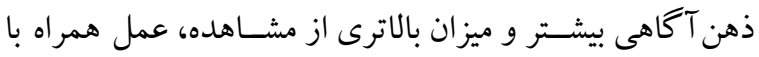

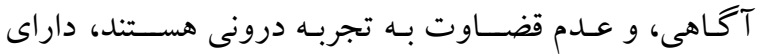
آشفتگى روانشناختى كمترى هستند و بالعكس. همبِنين نتايج

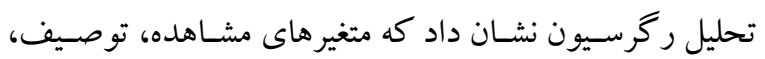
عدم قضـاوت به تجربه درونى و ذهن آكاهى با اطمينان 99

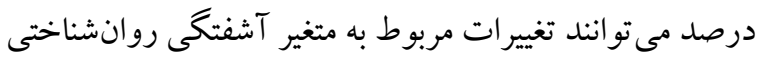
مادران داراى كود كان مبتلا به اختلال طيف اوتيسم را بهصورت منفى بيش مينى كنند. اين يافته ها به طور ضـمنى با نتايج كلدين

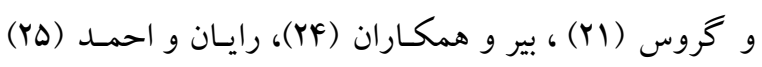

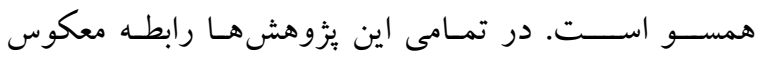

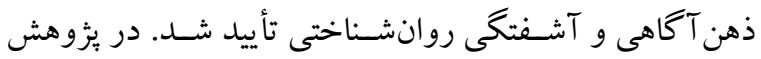
رايان و احمد (YD) نشـان داده شـــ كه مادران داراى كودكك مبتلا به اختلال طيف اوتيسم، آشـفتخى روانشـناختى بالايى را

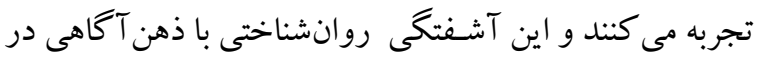

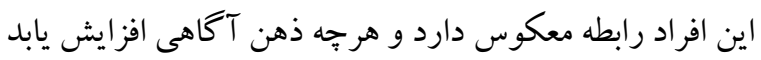
آشفتخىروانشناختى در اين گرووه از مادران كاهش مئ ديابد.

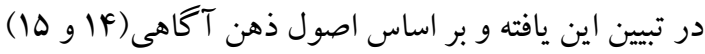
كه بر هشـيارى غيرقضـاوتى و مبتنى بر زمان حال و همجنين

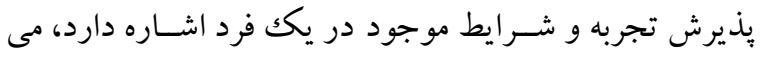

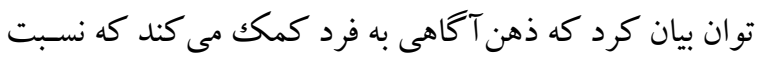

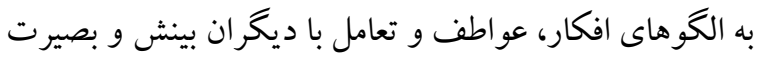
بيدا كند و سـبس بتواند به صسورت ماهرانه باسـخ هاى هدفمند 
كود كك اختلال طيف او تيسم كه نشخوار فكرى بيشترى دارند، آشفتخى روانشناختى بالاترى را نيز تجربه كنند.

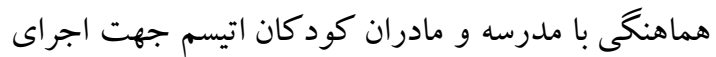

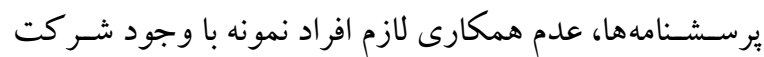
رضـايتمندانه آنها، عدم كنترل دقيق تمامى متغيرهاى مزاحم

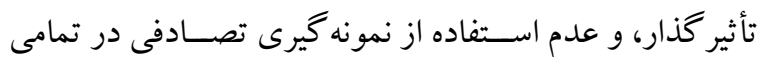
مر احل انتخاب نمونه، از جمله محدوديتهاى اين يُوهش بود

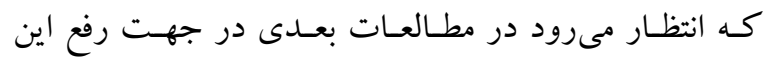
محدوديت هاى روششـناختى اقدام شـود. با توجه به نتايج به

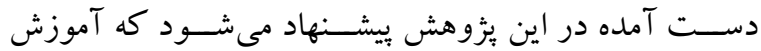
ذهن آكَاهى و مقابله با نشــخوار فكرى براى والدين كود كان

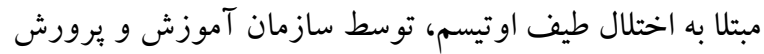

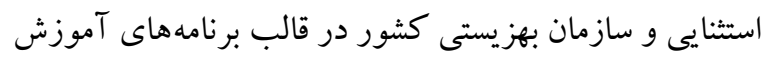
خانو اده در مراكز آموزشى و توانبخشى، در دستور كار قرار

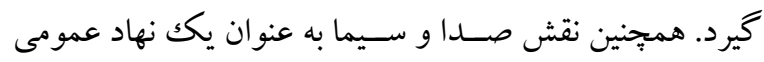

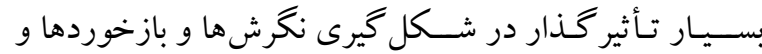
افزايش سـطح دانش عمومى و تخصـصسى افر اد جامعه، نبايد

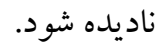

تشــكر و قدردانى: اين مطالعه به صــورت مســقل و با صــدور

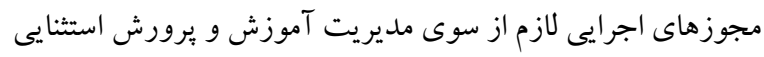

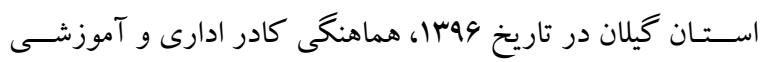

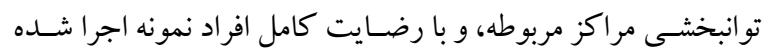

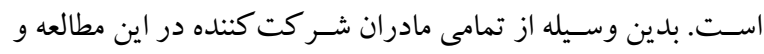

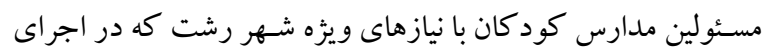

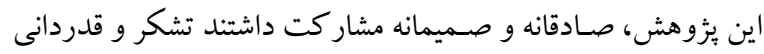
مى شود.

تضـاد منافع: اين مقاله حاصل يك برزوهش مستقل است كه بدون

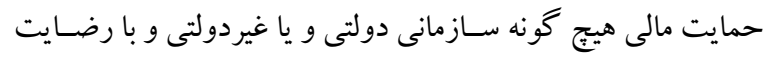

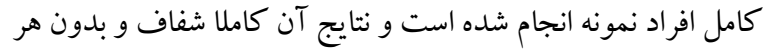

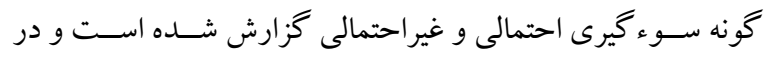
نتيجه هيج گونه تعارض منافع وجود ندارد.
فكرى تبين كرد. نشخوار هماند يك صفت يا ويز گى پايدار

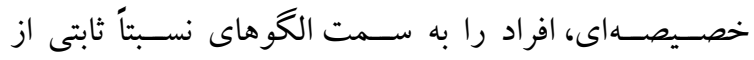
فكر كردن و رفتـار كردن در طول موقعيتهـا و زمـانهاى

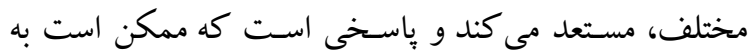

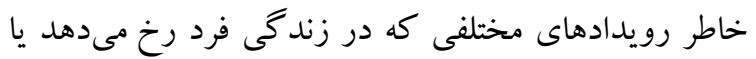
هيجانهاى مختلف مثل خشـم، افسردگى يا اضطراب، حاصل

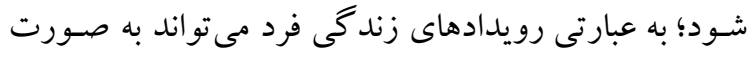

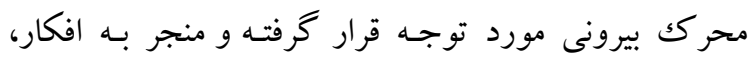

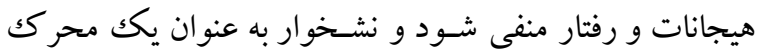
درونى، افكار، هيجانـات و رفتار منفى را ايجاد كند (آب). يُزوهش هاى مختلفى نشان دادهاند كه والدين كود كان مبتلا به

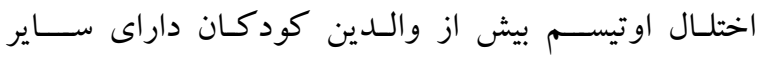
اختلال هاى روانشناختى، در معرض فشارهاى روانى ناشى از داشــتن كودك ناتوان خود قرار دارند (4 -1). فشــارهاى

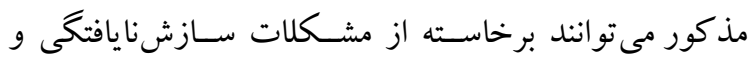
رفتارهاى ضدّاجتماعى، خود آسيبرسانى، حر كات كليشهاى و يا فشـارهاى روانى ناشسى از دشـوارى در برقرارى ارتباط

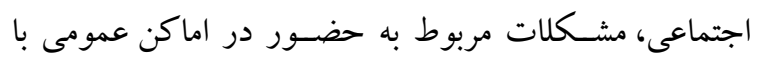
شرايط خاص جسمانى كودك،، و يا هزينهاى زياد خدمات

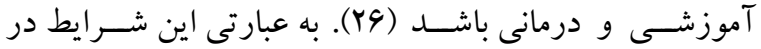

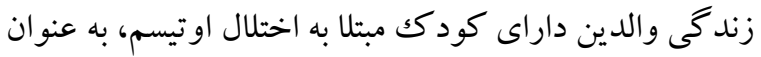

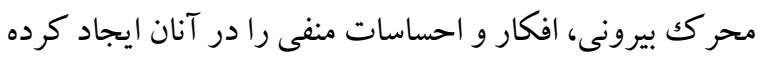
و نشــخوار به عنوان محرك درونى، اين افكار و احســاســات منفى را تشــديد مى كند. مادران داراى كود كك مبتلا به اختلال طيف اوتيسـم كه داراى نشـخوار فكرى منفى هســتند همواره

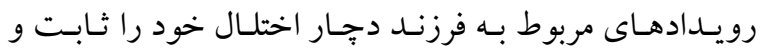
دوامدار تلقى كرده و همواره با بدترين حالت به آن مىنخرند؛ ترون

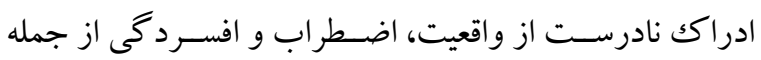
بيـامـدهاى نشــخوار فكرى در اين افراد خواهد بود كه زمينه آشــفتكى هاى روانشــناختى راد در مادران اين كود كان ايجاد

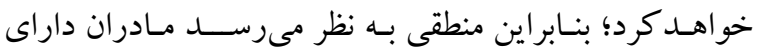




\section{Reference}

1. Moazzen M, Yaghooti F, Saleh J. Executive Functions in Parents and Siblings of Children with and without Autism Spectrum Disorders. Journal of Child Mental Health. 2015; 2(2): 85-91. [Persian]. [Link]

2. Zou M, Sun C, Wang J, Kang J, Xu Z, Ma Y, et al. Factors influencing the severity of behavioral phenotype in autism spectrum disorders: Implications for research. Psychiatry Res. 2018; 261: 290-297. [Link]

3. Miranda A, Mira A, Berenguer C, Rosello B, Baixauli I. Parenting stress in mothers of children with autism without intellectual disability. Mediation of behavioral problems and coping strategies. Front Psychol. 2019; 10: 464. [Link]

4. Askari M, Moridi J. Effect of stress management training and thought control strategies on the quality of life of mothers with childbirth in Bandar Abbas. The Journal of New Advances in Behavioral Sciences. 2016; 1(1): 1-13. [Persian]. [Link]

5. Ahmadi A, Raeisi Z. The effect of acceptance and commitment therapy on distress tolerance in mothers of children with autism. Journal of Child Mental Health. 2018; 5(3): 69-79. [Persian]. [Link]

6. Shokri S, Khanjani Z, Hashemi T, Esmaeilpuor K. Comparison of parenting stress and psychological distress in mothers of children with autism disorder and developmental delay. Journal of Child Mental Health. 2017; 4(3): 79-90. [Persian]. [Link]

7. Osborne LA, Reed P. Stress and self-perceived parenting behaviors of parents of children with autistic spectrum conditions. Res Autism Spectr Disord. 2010; 4(3): 405-414. [Link]

8. Dabrowska A, Pisula E. Parenting stress and coping styles in mothers and fathers of pre-school children with autism and Down syndrome. J Intellect Disabil Res. 2010; 54(3): 266-280. [Link]

9. Rivard M, Terroux A, Parent-Boursier C, Mercier C. Determinants of stress in parents of children with autism spectrum disorders. J Autism Dev Disord. 2014; 44(7): 1609-1620. [Link]

10. Lecavalier L, Leone S, Wiltz J. The impact of behaviour problems on caregiver stress in young people with autism spectrum disorders. J Intellect Disabil Res. 2006; 50(Pt 3): 172-183. [Link]

11. Tomanik S, Harris GE, Hawkins J. The relationship between behaviours exhibited by children with autism and maternal stress. J Intellect Dev Disabil. 2004; 29(1): 16-26. [Link]

12. Hastings RP, Johnson E. Stress in UK families conducting intensive home-based behavioral intervention for their young child with autism. J Autism Dev Disord. 2001; 31(3): 327-336. [Link]

13. Schieve LA, Boulet SL, Kogan MD, Yeargin-Allsopp M, Boyle CA, Visser SN, et al. Parenting aggravation and autism spectrum disorders: 2007 national survey of children's health. Disabil Health J. 2011; 4(3): 143-152. [Link]

14. Janowski K, Łucjan P. P-133 - Worry and mindfulness: the role in anxiety and depressive symptoms. Eur Psychiatry. 2012; 27(Supplement 1): 1. [Link]

15. Piet J, Würtzen H, Zachariae R. The effect of mindfulness-based therapy on symptoms of anxiety and depression in adult cancer patients and survivors: A systematic review and meta-analysis. J Consult Clin Psychol. 2012; 80(6): 1007-1020. [Link]

16. Joo HM, Lee SJ, Chung YG, Shin IY. Effects of mindfulness based stress reduction program on depression, anxiety and stress in patients with aneurysmal subarachnoid hemorrhage. J Korean Neurosurg Soc. 2010; 47(5): 345-351. [Link]

17. Song Y-S. Depression, stress, anxiety and mindfulness in nursing students. Korean Journal of Adult Nursing. 2011; 23(4): 397-402. [Link]

18. Masuda A, Tully EC. The role of mindfulness and psychological flexibility in somatization, depression, anxiety, and general psychological distress in a nonclinical college sample. J Evid Based Complementary Altern Med. 2012; 17(1): 66-71. [Link]

19. McManus F, Surawy C, Muse K, Vazquez-Montes M, Williams JMG. A randomized clinical trial of mindfulness-based cognitive therapy versus unrestricted services for health anxiety (hypochondriasis). J Consult Clin Psychol. 2012; 80(5): 817-828. [Link] 
20. Morone NE, Lynch CP, Losasso VJ, Liebe K, Greco CM. Mindfulness to reduce psychosocial stress. Mindfulness. 2012; 3(1): 22-29. [Link]

21. Goldin PR, Gross JJ. Effects of mindfulness-based stress reduction (MBSR) on emotion regulation in social anxiety disorder. Emotion. 2010; 10(1): 83-91. [Link]

22. Segal ZV, Williams JMG, Teasdale JD. Mindfulness-based cognitive therapy for depression: A new approach to preventing relapse. New York, NY, US: Guilford Press; 2002. [Link]

23. Forouzesh Yekta F, Yaghubi H, Mootabi F, Roshan R, Gholami Fesharak M, Omidi A. The effectiveness of mindfulness based stress reduction program on distress, emotion regulation and marital satisfaction in non-maritaly distressed women. Clinical Psychology Studies. 2018; 8(31): 67-90. [Persian]. [Link]

24. Beer M, Ward L, Moar K. The relationship between mindful parenting and distress in parents of children with an autism spectrum disorder. Mindfulness. 2013; 4(2): 102-112. [Link]

25. Rayan A, Ahmad M. Psychological distress in jordanian parents of children with autism spectrum disorder: the role of trait mindfulness. Perspect Psychiatr Care. 2018; 54(1): 11-18. [Link]

26. Bayrami M, Hassimi Nosratabad T, Besharat R, Movahedi Y, Kohpayma S. The study of the components of neuroticism among parents of autistic children, mental retarded and normal in the city of Tabriz. Exceptional Education. 2014; 9(122): 17-27. [Persian]. [Link]

27. Joormann J. Differential effects of rumination and dysphoria on the inhibition of irrelevant emotional material: evidence from a negative priming task. Cognit Ther Res. 2006; 30(2): 149-160. [Link]

28. Nolen-Hoeksema S, Wisco BE, Lyubomirsky S. Rethinking rumination. Perspect Psychol Sci. 2008; 3(5): 400-424. [Link]

29. Sukhodolsky DG, Golub A, Cromwell EN. Development and validation of the anger rumination scale. Pers Individ Dif. 2001; 31(5): 689-700. [Link]

30. Zhang W, Yan T, Du Y, Liu X. Relationship between coping, rumination and posttraumatic growth in mothers of children with autism spectrum disorders. Res Autism Spectr Disord. 2013; 7(10): 12041210. [Link]

31. Nezamipoor E, Abdolmanafi A, Besharat MA, Etemadinia M. Investigating the mediating role of the coping and problem solving styles on the rumination and depression in students. International Journal of Behavioral Sciences. 2015; 9(1): 61-69. [Persian]. [Link]

32. Mohseni-Ezhiyeh A, Malekpour M, Ghamarani A. The effect of transdiagnostic treatment on mothers of children with autism spectrum disorder. Practice in Clinical Psychology. 2016; 4(3): 199-207. [Link]

33. Baer RA, Smith GT, Hopkins J, Krietemeyer J, Toney L. Using self-report assessment methods to explore facets of mindfulness. Assessment. 2006; 13(1): 27-45. [Link]

34. Brown KW, Ryan RM, Creswell JD. Mindfulness: theoretical foundations and evidence for its salutary effects. Psychol Inq. 2007; 18(4): 211-237. [Link]

35. Ahmadvand Z, Heydarinasab L, Shairi MR. An investigation of the validity and reliability of psychometric characteristics of five facet mindfulness questionnaire in Iranian non-clinical samples. International Journal of Behavioral Sciences. 2013; 7(3): 229-237. [Persian]. [Link]

36. Treynor W, Gonzalez R, Nolen-Hoeksema S. Rumination reconsidered: a psychometric analysis. Cognit Ther Res. 2003; 27(3): 247-259. [Link]

37. Luminet O. 10 measurement of depressive rumination and associated constructs. In: Papageorgiou C, Wells A, editor. Depressive rumination: nature, theory and treatment. New York: John Wiley \& Sons; 2004, pp: 187-215. [Link]

38. Kessler RC, Andrews G, Colpe LJ, Hiripi E, Mroczek DK, Normand SLT, et al. Short screening scales to monitor population prevalences and trends in non-specific psychological distress. Psychol Med. 2002; 32(6): 959-976. [Link]

39. Yaghubi H. Psychometric properties of the 10 questions Version of the Kessler Psychological Distress Scale (K-10). Journal of Applied Psychology Research. 2015; 6(4): 45-57. [Persian]. [Link] 